Ljubica Matek, Josip Juraj Strossmayer University of Osijek, Croatia - Zvonimir Prtenjača, Josip Juraj Strossmayer University of Osijek, Croatia

\title{
No Country for Old X-Men: The Aging Hero in No Country for Old Men and Logan
}

\section{Abstract}

The American Western is imbued with a particular elasticity, which allowed it to stay relevant for decades. One of the recent developments in the genre seems to be its focus on the aging frontiersman - a hero past its prime. A faithful adaptation of Cormac McCarthy's 2005 novel, the Coen brothers' eponymous film No Country for Old Men (2007), departs from the traditional Western by outlining an aging lawman, Sheriff Ed Tom Bell, struggling to live up to his role. Similarly, James Mangold's Logan (2017) forces the titular pop-cultural superhero icon to endure the deconstruction of its archetypal alter ego, the Wolverine. The underlying themes of the two films intersect, representing their aging protagonists both as evocations of their own previous, abler selves, and as elderly frontiersmen in a world with hardly any space for aged (super)heroes. Their fluctuating identities challenge the traditional, idealistic representations of patriarchal Western heroes by introducing a more realistic and complex concept of an aging hero both into the universe of the neo-Western genre and into popular culture.

Keywords: No Country for Old Men, Logan, neo-Western, frontiersman, hero, superhero aging

That is no country for old men ...

An aged man is but a paltry thing,

A tattered coat upon a stick ...

(Yeats 1, 9-10) 
The neo-Western's status as a prominent scholarly topic arises from its continuous attempts to critically reassess the codifications of "the West as a formative space of the United States' national identity" (Paul 341). In many ways, the identity implied is one of rugged masculinity, which contributes to the "pre-given or pre-defined mythology of a triumphalist America formed in the frontier West" (Campbell, "Defining Post-Western Cinema" 6). The most notable way in which the neo-Western questions, or, as Gilles Deleuze suggests, in which it demonstrates the breakup of the perceived sense of unity (Cinema 2 216), is by introducing a specific sensibility. In the case of the Coen brothers, sensibility has to do with affect and the perception of masculinities represented not so much as "wrestling" with the antagonists as with one's own soul (Campbell et al. 313-14). Building on these ideas, this paper intends to analyze the Coens' film No Country for Old Men (2007) and James Mangold's Logan (2017 $)^{1]}$, in order to indicate that the neo-Western represents the aging hero as a more realistic and complex character, opposing the outdated, traditional representation of an atavistically masculine hero.

By bending the pre-set time-space framework of the traditional Western, the neo-Western not only introduces its characters to the contemporary world, as opposed to the initial late-nineteenthcentury setting, but as Deleuze suggests, it also relies on the ellipse as the "small form" that highlights what is opposable (Cinema 1 166), namely, unique or different ${ }^{[2]}$ This subset promotes the break-up of the previously outlined codes, further abandoning the classic binary representation of the protagonist as persistently well-intentioned and the villain as unequivocally evil. In fact, according to Deleuze, there is no such thing as a clear-cut identity in the neo-Western, but rather identities (or groups) multiply, proliferate and create such complex relations and alliances that they become incongruous and indistinguishable in their constantly shifting oppositions (Cinema 1 167). Therefore, the neo-Western ${ }^{[3]}$ approaches the idealization of both the lone frontiersman and the pastoral setting he operates in (Lawrence and Jewett 161) more ambiguously. These departures both necessitate and enable analyses of different focal points related to the traditional frontiersman's mind-set and body since, as John G. Cawelti suggests, the cultural myths they once exemplified are no longer entirely suitable to the contemporary imaginative needs (260). More specifically, the paper focuses on the issues related to the representation of aging protagonists who are unable to perform the roles of idealized frontiersmen. The neo-Western directly confronts 
this phenomenon by representing change as an exponential evolution, since both Bell and Logan are affected by forces that become more frequent and intense with time (JohnArthur), as a direct result of their aging. Thus, the two protagonists are delineated as Western heroes of an erstwhile age who are suffering from shattered physical and mental resilience. Jim Welsh's observation that renewed Westerns convey the confusing logic of the "frustrated frontier" affected by an "evil with a postmodern spin" (81), undoubtedly finds its footing in scholarly analyzes about old age as the ultimate contemporary "evil" displayed in the film through visible signs of aging.

Although the films seem to accept what Cawelti would call a kind of cultivation of nostalgia and its reassuring deployment of generic features used to reconstruct the aura of a past time, the dialectic between conventional and inverted meanings is used to demythologize an established set of tropes ${ }^{[4]}$ A stock character or a style can be reinvigorated through the reaffirmation of myth as an echo of authentic human ambitions and needs (Cawelti 253-58). The two films engage in an interesting conversation with the very essence of nostalgia that permeates both of the titular protagonists, thus tipping into the crux of their matter by simultaneously deconstructing and reaffirming their statuses as traditional frontiersmen. The premise that the Western genre relies on the actions of its heroes and villains (Campbell, Postwesterns 11) implies that the concept of the Western hero is a solid phenomenon, fixed and easily recognized in popular culture. According to Douglas B. Holt and Craig J. Thompson, the mythologized cowboy exemplifies masculine ideals, which include "rugged individualism, an adventurous spirit, risk-taking, displays of physical prowess, and most of all, a high degree of personal autonomy" (425-26). By depriving the heroes of No Country for Old Men and Logan of these masculine traits, the neo-Western challenges the Western masculine ideal as the clash between the "atavistic ideal masculinity and the modern breadwinner role produces an identity crisis" (Holt and Thompson 426). The fluctuating identity of protagonists echoes Deleuze's notion of the reversal of the outside and the inside (Cinema 1 167), which takes place in Howard Hawks' films, the subject of Deleuze's analysis. What Cawelti refers to as generic transformation, for Deleuze is "a transformation of the form" ensured by reversals that represent "functional permutations" - "The outside and the inside thus become external to one another, they enter into a purely linear relationship, which makes possible a functional permutation of the opposites" (Cinema 1 166). To illustrate the permutation of the characters' roles as both 
heroes and the defeated ones, the paper will turn to Sheriff Ed Tom Bell's and Logan's (James Howlett's, Wolverine's ${ }^{[5]}$ first on-screen appearance.

Throughout their filmmaking oeuvre, the Coens have established themselves as postmodern auteurs, constantly "interrogating genre by participating in it, playing with its various forms, and skillfully manipulating the knowledge built up by its audience to de-territorialize the assumptions and values bound up with their understanding" (Campbell, Post-Westerns: Cinema, Region, West 332). It is therefore unsurprising that they toy with the essential heroic mechanisms early on in No Country for Old Men, beginning with the protagonist's introduction. Herein, they allow no space for traditional Western staples such as fair maidens, worried good-byes, magical landscapes, or the gunslinger's dramatic departure. This is rendered explicit in a brief, nevertheless illuminating, exchange between Sheriff Ed Tom Bell, and his wife, Loretta.

Loretta: Be careful.

Ed Tom: I always am.

Loretta: Don't get hurt.

Ed Tom: I never do.

Loretta: Don't hurt no one.

Ed Tom: Well, if you say so. (No Country for Old Men 00:28:09 - 00:28:17)

The Coens hint at the deconstruction of the hero archetype before his journey has even commenced. They oppose the character of Ed Tom Bell to the traditional image of the hot-headed, fearless, gun-toting cowboy, and paint him as weary, passive, stagnant, and even somewhat averse to performing his duties. Moreover, Bell insinuates that the patriarchal West - and thus the patriarchal hero - no longer exists, since he is not merely deferential, but almost obedient to his wife.

Mangold, on the other hand, takes a subtler approach to achieve the same aim but remains unwavering in positioning his film as an effective critique of "superhero fiction itself through the employment of several Revisionist Western motifs" (Steinberg). The superhero setting is translated into the traditional Western setting, therefore bringing two of the most prominent American hero 
characters - the cowboy and the superhero - to the same ground and enabling a comparison with the neo-Western, or an analysis from the point of view of the genre. Thus, the opening sequence tellingly dismantles Logan's heroic entrance, refusing to support the conventions of both the superhero film and those of the Western. Specifically, the camera pans in on Logan, "the once unconquerable Wolverine, deemed a lethal adversary by his enemies and a relentless protector by his friends" (Flores 161), now seen as a weary, visibly older man, whose resting time is interrupted by a Mexican gang somewhere near the United States-Mexico border. While a gang of criminals is trying to strip his limousine, the only source of his income, for parts, Logan does not attack them but merely verbally warns them to stop, failing to satisfy the viewers' expectations arising from his previously physically explosive filmic incarnations. Logan is reluctant to unsheathe his claws and fend off the attackers until the gang members shoot him and later threaten him with metal bars. Only at this point does Logan engage in a visceral sequence which, in nearly all of its conventional mechanisms, conforms to the prototypical superhero playbook. What stands out is the image of an old(er) superhero. The viewer does not encounter a mighty figure in its heyday, but rather a "former X-Man who is not only visibly old, ill, and drunk, but also struggling financially" (Petković 136); in other words, deteriorating in all aspects.

To further highlight the sense of decay and de-masculinization that is implied to come with old age, the film represents other aged heroes living with Logan; a defunct Mexican smelting plant serves as a makeshift asylum for the ailing nonagenarian that is Charles Xavier, once the powerful Professor X and now "a telepathic Alzheimer patient in a wheelchair", and for Caliban, a sixty-yearold "albino with severely restricted mobility" (Petković 137) whose mutant-tracking abilities make him, in his own words, "a glorified truffle pig, not a clairvoyant" (Logan 00:27:19 - 00:27:21). Himself "a middle-aged man who exhibits unmistakable cancer-like symptoms" (Petković 137) in the form of bloodied tissues and straining coughs, Logan barely sustains the damage done to his once-imposing body, which is now slowly being eaten away by his dilapidating adamantium skeleton. These representations are in line with contemporary scholarly views on age and aging. For example, Stela Dujakovic argues that the increase in life expectancy has popularized the issue of old age in literature, and foregrounded its access into mainstream culture (470), which, to a certain extent, may explain the way Logan and the other two aged X-Men have been represented 
in the film. More to the point is Rüdiger Kunow who contends that old age represents a point of intersection between biology and culture, i.e., between the material reality of our bodies and the cultural representations in which a community recognizes itself (24), possibly suggesting that the perception of old age in the Western culture is chiefly a negative one, implying weakness, incompetence, and impotence. Ultimately, the process of aging - if not interrupted prematurely by the death - is particularly intertwined with the issues of a steady decline toward disability, which challenges the notion of hegemonic masculinity since disability "feminizes all disabled figures" (Garland Thomson 9). These implicit and explicit brandings "of human frailty ... incongruous with the protagonist's mythic status" (Cloutier 113) point to their functional permutation and highlights a tonal change that seeps into the cracks of the characters' identity[ $[$ ]

Embodying the Deleuzian functional permutations, both films "offer a new script for older men in the struggle for a viable masculinity" (Saxton and Cole, "No Country for Old Men: A Search" 98). On the one hand, they visually support the prototypically commanding gunslinger iconography: the camera lens never shies away from Sheriff Ed Tom Bell's white hat and shiny badge, always reminding the viewer of his lawman status, and Logan undoubtedly dominates most of the frames in his white tank-top and brown boots, with a gravitas exuded by the 1960s mavericks. On the other hand, both the Coens and Mangold juxtapose these powerful archetypal configurations with a poignant visual marker that further emphasizes the obvious signs of Logan's and Ed Tom Bell's aging; the reading glasses enfeeble their sight of the current times and are indicative of their remolding into "post-heyday frontiersmen who violate the genre because their bodies are ill-fitted for the job, plagued by frailty, ineptitude, and illness" (Cloutier 113).

Whereas Bell's age is predominantly signified through his mental state and attitude about the present time, Logan goes to great lengths to assert that its titular character has physically fallen victim to the passage of time, a self-destructive malaise, and the eventual deceleration of his previously unbridled regenerative abilities. His aging appearance becomes both an intimate and public matter, one rendered abundantly clear to the viewer by Logan's closest "relatives," Charles and Caliban. Save for a handful of nauseating shots revealing Logan's tattered body forcefully spewing out bullets or him slashing his pus-covered knuckles and palms because of the semi- 
protracting claws, Caliban delivers the most striking description of both Logan's body, and his frame of mind:

I hear you at night. You aren't sleeping. You don't want to talk about that. Or the booze you're drinking or the pus you keep wiping from your knuckles or the blood I wash from your clothes or those brand new holes in your chest that haven't healed. And I very much doubt you want to talk about the fact that you can't read the label on the side of that bottle. It's Ibuprofen. ... Something's happening to you, Logan. On the inside. I can smell it. You're sick. (Logan 00:19:19 - 00:20:11)

Similarly, Charles addresses Logan's fading eyesight, stating that he likes his glasses since they "make him look younger" (Logan 00:24:34 - 00:24:36)! Caliban's and Charles' statements thus construe an outward exposition of Logan's ailing visage, yet they never question his role as their "family's" chief caregiver and provider. Although he is clearly challenged by the limitations of his age and "consumed by the stress of caring for a chronically ill Charles Xavier," his surrogate father "to whom he feels as emotionally attached as anyone on the planet" (Flores 163), Logan remains extrinsically and intrinsically motivated to act. The film thus insists on "the constant mechanism of reversals" (Deleuze, Cinema 1 166), which accounts for the aging character's complexity. In this regard, Logan calls upon the sentiment "that the sick, old men ... may in fact be the only ones who can do the job the way it needs to be done" (Cloutier 117). Thus, it does more than simply justify its label of "Unforgiven with claws" (Mooney) ${ }^{[8]}$ conceptualizing the message it shares with No Country for Old Men, even though the two films are situated in vastly different narrative frameworks, the idealized patriarchal hero no longer exists.

Unlike Logan, who is cognizant of the aching process which has befallen him, and is attempting to alleviate it (albeit through alcohol, medication abuse, and contemplation of suicide), Bell accepts his situation of "the odd man out" in a world where traditional rules and values of the old West no longer apply, without attempting to do much about it. By deploying the opening voice-over narration, the Coen brothers offer an introspective view of Bell's state of mind, illustrating his disorientation in a society of rapidly changing codes. In the face of the ever-growing crime rate, Bell cannot believe that "he was sheriff of this county since he was twenty-five" (No Country for Old Men 00:00:40 - 00:00:43). Rather than showing wisdom and understanding of the county's 
peculiarities, he exudes disappointment, fatigue, and insecurity about his purpose in life. This is further exacerbated by his bafflement at the corrupt world, and reluctance to pursue his career or jeopardize his traditional point of view: "A man would have to put his soul at hazard ... and say, okay, I'll be part of this world" (No Country for Old Men 00:02:30 - 00: 02:42). Bell thus chooses to think about the "good old days," his mode of thinking being a retrospective one, and his one pleasure "to hear about the old-timers. Never missed a chance to do so" (00:01:13 - 00:01:19). Establishing a connection between the past and present, Bell "can't help but wonder how they would've operated these times" (00:01:20 - 00:01:27). Ultimately, how these old-timers would react to such a rapidly changing world proves to be irrelevant as Ed Tom Bell, more than ever, literally and metaphorically begins to feel that he is forced out of his comfort zone and compelled to face "the consequences and reverberations within the contemporary world" (Campbell, Post-Westerns: Cinema, Region, West 332). The nostalgia he evokes is shattered, and his "untimely, ageing, uneasy figure" assumes the role of a "choric seer reflecting un-heroically on the state of this region in the world picture" (Campbell, Post-Westerns: Cinema, Region, West 332).

Logan is, on the other hand, metafictionally aware that he is no longer the comic-book stalwart that he was at the beginning of his on-screen journey, most notably in Bryan Singer's X-Men (2000) and X-2 (2003). Referencing the heroic showdown, he disintegrates Charles' dreams by issuing a painful reminder that "the Statue of Liberty was a long time ago" (Logan 00:14:58 - 00:15:00). He flicks through one of the comic books depicting the X-Men, the only proper family he ever had that is now gone because of, as is later revealed, Charles's murderous telepathic seizures accumulated in the Westchester incident, and scoffs ironically. In this way, Logan both denounces his cowboy image and denies the glorification of his past superhero ventures. The implied discourse with both of the characters' past (which lies outside of the narrative of the two films) "does more than simply intensify the genre's elegiac tone: it takes over where elegy cannot go, partly because it offers a meditation on the phenomenology of aging," (Cloutier 111) and its relationship to life and death. Indeed, the issue of power over life and death seems to be one of the crucial aspects in the analysis of the aging heroes. According to Michel Foucault, "biopower" encompasses "numerous and diverse techniques for achieving the subjugation of bodies and the control of populations" (140). As a result, suicide becomes the act of resistance (Foucault 139), in particular for jaded 
individuals such as aged, disabled superheroes. For example, Logan's forlorn attitude is seen both in the fact that he hides an adamantium bullet intended to end his life and in his pessimistic perception of the nature of X-Men, which he does not view as extraordinary, but as disabled: "You always thought we were part of God's plan. Maybe we were just God's mistake" (Logan 00:15:10 00:15:19). The X-Men were seen as special due to their physical capabilities, and the body they inhabited seemed to have fully enveloped their identity. They did not "exist," unless they were special, extraordinary, and different. Their relationships hardly mattered since they were perceived as weapons or tools, valuable so long as they function properly. According to Garland Thomson, "[p]hysically disabled bodies that qualified as prodigies ... extraordinary bodies have been so compelling - so valuable - as bodies throughout human history that whether they were alive or dead had little consequence" (57). Understanding himself as merely a body, robbed of his family, strength, and purpose, Logan is reluctant to bond with Laura. On the one hand, he rejects the necessity, or even possibility of forming new relationships since his life is nearing its end anyway, and on the other hand, he perceives loss as the only possible outcome of close relationships. Furthermore, Laura is in danger and need of protection and help, whereas his negative self-image, structured around his body as his source of worth, leads him to believe that, being weak and ill, he cannot be of any help; rather, any involvement will only cause him more trouble. Although she is bred and mutated from his genetic imprint by the corrupt Alkali-Transigen company, he refuses to perceive her as a substitute for family until the very end of the film. The family stands here as an opposition to the powerful and corrupting environment, which is also seen in No Country for Old Men; whether in conversation or his dreams, Bell keeps turning to his family for advice and guidance: his wife, his uncle, and his late father. The family is a haven from the "real world," and Logan makes this abundantly clear: "In the real world, people die, and no self-promoting ass*ole in a leotard can stop it" (Logan 00:56:55 - 00:57:00). In this, he also utters a truth that plagues Bell, namely, that individuals have very little control over their lives, and once they no longer serve the system, they are discarded. As tortured Logan speaks of superheroes in leotards as passé in the apocalyptic new West, so Bell knows that his sheriff's badge, gun, and cowboy hat are not enough to push him through the gritty present. 
As a result, both of the aging cowboys seem to be morally and physically overmatched by the rapidly changing social and ethical conditions of their time, in which amoral killers seem to be operating outside of every known motivational framework. Additionally, the criminal opponents tend to be younger and abler than both Bell and Logan, which reinforces the binary construction of "young" and "old," based on the Western perception of old age, that is, a biogerontological model according to which aging equals decline. To emphasize this, the two men face antagonists who seem to possess all the qualities that the aging cowboys do not. According to Jakub Ligor, Anton Chigurh can be read as a "fantastic being that seems to have come from another dimension to impose his own rules on both the film's projected reality and all the other characters" (75). His mysterious aura arises from his calculated actions and inscrutable demeanor, underlined by an utter lack of knowledge about his origins or history, continuing the "tradition of alienated Coenesque antagonists ... whose deeds violate all established social norms" (75). His Grim Reaper-like appearance is enhanced and updated by his exotic scythe, a pneumatic bolt pistol for killing cattle, which serves as a bodily extension in line with "the taciturnity and heartlessness of this mechanized killer" (Tyrer and Nickell 90). On the other hand, Logan's antagonist is actually a pastiche of three separate entities, the first being the amorality of Alkali-Transigen's president and the surgical head, Zander Rice, who codenames unnaturally mutated children X-23s and refers to them only as experiments and "things with patents and copyrights" (Logan 00:46:43 - 00:46:45), emphasizing the idea of them being bodies, and not persons. Since he mostly operates from the shadows, Rice relies on the cybernetic enhancement of the Reavers, a group of mercenaries led by Alkali-Transigen's unscrupulously relentless head of security, Donald Pierce, to track down and torture his enemies. The murderer's role, however, is attached to X-24, another one of Logan's feral clones and a blunt instrument imbued only with an artificially produced, single emotion, namely rage.

Still, what ultimately deconstructs the very notion of the heroes in the titular films is not just their reluctance or inability to physically confront their formidable enemies that foster many new, harmful designs, but also their failure and unwillingness to understand them. For example, while entering one of the premises during his search for Chigurh, Bell hides behind his young deputy, Wendell, and refuses to unholster his handgun. In doing so, he adopts "a shamefully passive strategy of 
survival," whereas his "approach of an almost stoical, dejected observer of escalating crime and bloody drug wars" - events focalized around Chigurh's essence - constitutes "a radical departure from the idealistic stance of classic Westerns" (Ligor 77). Campbell et al. describe this particular instance in the film as "a classic kind of 'the bubble has burst' moment where the conventions of the classical action hero are no more," (329) a process which is reiterated many times in the film. For example, Bell's unwillingness to perform his duties as a Sheriff of the remote Terrell County is rendered explicit in his conversations with his deputy:

Wendell: The Rangers and the DEA are headed back out to the scene this morning. You gonna join 'em?

Ed Tom: Any new bodies accumulated out there?

Wendell: No sir.

Ed Tom: Well then, I guess I can skip it. (No Country for Old Men 00:42:29 - 00:42:41)

Even though his cooperation with the mentioned agencies could hasten his investigation and the search for Chigurh, as well as resolve all of the emerging conundrums, Bell simply "skips" the possibility of collaborating with another law-abiding force. Consequently, he does not fully challenge the obstinate ethos of the archetypal hero (or the old West) as he mostly acts on his own, like a rugged frontiersman, but fails to establish a partnership with an aiding figure, a recurring trope of the traditional Western, which could help him defeat his enemy. On the whole, Bell expresses his bewilderment with the world as he ironically isolates himself following an outdated chivalric code of honor which further underlines his powerlessness: "My God, Wendell, it's just all-out war. I can't think of any other word for it. Who are these people?" (No Country for Old Men 01:26:36 - 01:26:42).

In a similar desire for isolation and evasion of conflict, Logan refuses to use firearms, despite the fact that his "weapon" - his body - is rapidly weakening. He also hopes to amass money for the Sunseeker, a boat which embodies his and Charles' desire to save the world from Charles's seizures that are becoming more difficult to control by withdrawing from that same world. Their inability and unwillingness to keep fighting can be said to symbolize the collapse of the notion of a traditional hero. They wish to find refuge in the water, "perhaps hoping for a peace evocative of the 
Pacific Ocean as the limit of westward expansion" (Mooney). However, at Charles' behest, Logan abandons this idea in order to help Laura, which creates what seems to be Logan's "most enduring family triangle, a multigenerational one: Xavier-Logan-Laura," (Wheeler Vega 463) ${ }^{[9]}$ and which will haunt Logan up to his demise, outlining his redemptive arc in the process. Therefore, as Bell declines "to push his chips forward and go out and meet something he don't understand," (No Country for Old Men 00:02:18 - 00:02:26) and as Logan initially refuses to help Laura and Gabriela reach the sanctuary in North Dakota, the viewer seems to be deprived of a superhero's journey, or any kind of heroic quest, for that matter. Rather, their reluctance to act as heroic figures arises from their struggle with aging; the way they deal with the realization that their prime has passed gives both of the films a sense of melancholy and loss. In a sense, the very essence of the archetypal character they were supposed to embody is relegated only to a shallow silhouette: Bell's "age has flattened him," (No Country for Old Men 00:29:23 - 00:29:25) whereas Logan succumbs to being "someone who looked like the Wolverine", someone "who looked old" (Logan $00: 22: 10-00: 22: 15)$. It is precisely this perceived indignity of the old age that is debilitating for Logan, who, according to Suzana E. Flores, has always taken pride in his ability to protect the precious few he cares for, which he is now unable to do (163).

Ultimately, they reach a point where a traditional Western showdown should occur, albeit in a setting they are not accustomed to. This is also the point of critical departure in the comparative analysis of the titular characters. Sheriff Bell, reluctant to even act against Chigurh, arrives to meet him at a motel in an urban area. In the film's only instance where he unholsters his weapon, thus becoming the gunslinger whose job "necessitates to effectively engage the enemy and adopt some of his techniques so as to turn them against him," (Hawkins 14) no real showdown occurs; Bell is represented as the shadow of the lawman he used to be. Although Bell is allowed to return to his home and his wife, he remains encumbered with the impossibility to secure his internal peace. According to Benjamin Saxton and Thomas R. Cole, he is both deprived of the social props and privileges of the cowboy hero and overwhelmed by the realization of his impending retirement and death, which, for him, are ultimately the same thing ("No Country for Old Men: Four Challenges" 611). 
On the other hand, Logan, who in his late days seems fully accustomed to "the usual superhuman cityscape," (Huw Bowen 207) is forced to replenish his already battered body with a super serum to become a superhero one last time. During his final fray against the Reavers, Logan encounters shadows of his former and future self. As he battles X-24 -his physically superior clone and the literal object of his internal demons that have been haunting him throughout his entire life - he is mortally wounded. Yet, he is metaphorically "saved" by his daughter, Laura, who decapitates X-24 by firing the previously mentioned adamantium bullet. In doing so, she erases Logan's haunting past and acts as an extension of his future. Although Logan dies at the cusp of the US-Canada border, bringing his life cycle full circle without allowing him to re-enter what was originally his home, his final battle seems to have a more positive meaning - it merges the ideas of mutation, mutant body, and purported American ideals, (Asif et al. 154) that are, indeed, heroic ideals. In fact, according to Saljooq M. Asif et al., "Logan's sacrificial death in the idyllic forests of Eden - his literal and metaphorical fall - offers the children a new beginning as they flee to Canada," (154) signaling the conclusion of his redemptive arc. What remains, however, is the unambiguous representation of aging as decay. Testifying to this, Jason A. Wheeler Vega suggests, somewhat humorously, that Logan is "a film that might have been subtitled A Portrait of the Superhero as a Middle-Aged Man," (455-56) alluding to Joyce's Bildungsroman in which the young hero is represented on his way to maturity. As Logan barely negotiates his existence between Charles' abasing old age and Laura's youthful vigor, the viewer confronts the fact that he "has been poorly prepared in his long superhuman life for facing the challenges of mature adulthood with a sense of generativity," (Wheeler Vega 456) and death.[10]

Interestingly, Bell faces the same issues after retiring due to his inability to confront the imposing force of evil embodied by Chigurh. By the end of the film, his status of an aging ineffectual cowboy, who has not only "departed from the traditional masculinity scripts of the American Western" but also "renounced the violence that sustained his male dominance, and lost the moral certainty that ensured his identity," (Saxton and Cole, "No Country for Old Men: Four Challenges" 610) is affirmed. Although utterly emasculated, he is not even fit for housework, traditionally a female domain, which underlines his futility: 
Ed Tom: I mean, would you care to join me?

Loretta: Lord no. I'm not retired.

Ed Tom: Maybe I'll help here then.

Loretta: Better not. (No Country for Old Men 01:54:25 - 01:54:35)

As the spouses proceed to make plans for the day, Bell explains that he dreamt of his father, who "was goin' on ahead ... fixin' to make a fire somewhere out there in all that dark and all that cold" ( No Country for Old Men 01:56:09 - 01:56:12). Bell thus not only returns to daydreaming about the roles of the traditional Western hero, an image that has consumed him to a point where he can no longer escape it, but also reiterates the nostalgia he felt towards the old-timers as the exact conception, which, it can be claimed, has defeated him in the face of the new West ${ }^{[11]}$ In line with the notion of Deleuzian functional permutation, a form of redemption is offered by suggesting that Bell is not unique in his failings. It comes from his disabled uncle Ellis, who claims that Bell's experience is nothing new, as "this country" has always been "hard on people", and he "can't stop what's comin.' Ain't all waitin' on you. That's vanity" (No Country for Old Men 01:47:02 - 01:47:22). By the same token, as Mangold suggests in several subtle frames, Logan does not deviate too much from this pattern of a man who is neither fit for physical confrontations nor fully adapted to life at home. Sometimes he cannot find Charles' pills, even though they are always in the "bottom left" (Logan 00:11:13 - 00:11:25) corner of the cabinet stacked with medication, but he ensures that Charles and Laura are cared for. He even assists the Munson family in fixing their water pump sabotaged by Canewood Beverage's ${ }^{12]}$ thugs, and yet he can never "take a moment to feel" and fully adjust to the serene life defined by Charles as "a home, people who love each other, ... a safe place" (Logan 01:15:53 - 01:16:01). Circling back to Eastwoodian figures as embodiments of rugged American heroes, Sally Chivers, in her thought-compelling examination of Gran Torino (2008), establishes a cogent argument that the domestic motif is the dominant symbol in conceptualizing these heroes (120), and both Bell and Logan seem to fail at adapting to the domestic environment, while simultaneously being physically unable to keep fighting criminals. In the long run, and despite their "humble ambitions ... to remain virile and at peace", neither Logan nor Ed Tom Bell can "accept physical changes that come with age, be they knee problems, 
susceptibility to infection, or cancer" (Chivers 120). Ultimately, Logan's status as "the mutant superhero who belonged to the X-Men, and the impoverished, seriously ill elderly man with no medical insurance" (Petković 141) is apotheosized, ${ }^{[13]}$ as is the fact of the permutation of his functions in a neo-Western. He not only dies a hero but also becomes a mythic cowboy who both denied and accepted the conventions of his role. Moreover, even though his mutations challengingly align with the limitations of his age, Logan's fiercest superpower is ultimately revealed to be his maturation into Laura's father. As he finally comes to terms with "what it feels like" (Logan 02:08:04) to be a part of a family, one Wolverine's swan song is sung, and another one's only begun.

In conclusion, No Country for Old Men and Logan meet at an interesting juncture - both as generic permutations, either of the Western or the superhero genre, occurring in the light of contemporary concerns about aging. The films, through the process of continuous re-codification of the aging hero, challenge the idea of the traditional masculine hero as one-dimensional. The introduction of old age as a new form of "evil" plaguing the heroes, re-creates them as more realistic and sympathetic characters, imbuing the genre with a new life since it rejects stereotypical depictions of a hero. Through the lens of the frontier and the hero myth which constantly permeate popular culture, the films critically reassess the representation of traditional masculinity and heroism. In particular, by representing heroes who survive into old age, the films offer visual representations of weakness, illness, and decay framed by the memory of their previous heroic feats. Thus, they create space for the elderly and disabled protagonists, who can be seen as both demythologized and reaffirmed. In line with Deleuze's notion of functional permutation and Cawelti's generic transformation, they refuse to support the conventions of the traditional genres they occupy and challenge. James Mangold's essay about Shane coalesces into a fitting concluding thought for this analysis, as both No Country for Old Men and Logan bookend the neo-Western as a genre that encompasses far more than just sunsets, gunslingers, horses, showdowns, and saloons; these pop-cultural artifacts represent stories that intersect the present with the past in order to provide a better understanding of the characters' complexity and to depict more relatable, more human (super)heroes. 


\section{Works Cited}

Asif, Saljooq M., et al. "From Bodies to Borders and Beyond: Mutating Boundaries in Logan." Literature and Medicine, vol. 37, no. 1, 2019, pp. 141-65.

Campbell, Neil. “Defining Post-Western Cinema: John Huston's The Treasure of the Sierra Madre (1948)." New Wests and Post-Wests: Literature and Film of the American West, edited by Paul Varner, Cambridge Scholars Publishing, 2013, pp. 2-20.

Campbell, Neil. Post-Westerns: Cinema, Region, West. U of Nebraska P, 2013.

Campbell, Neil, et al. "From Blood Simple to True Grit: A Conversation about the Coen Brothers' Cinematic West." Western American Literature, vol. 48, no. 3, 2013, pp. 312-40.

Cawelti, John G. "Chinatown and Generic Transformation in Recent American Films." Film Genre Reader III, edited by Barry Keith Grant, U of Texas P, 2003, pp. 243-62.

Chivers, Sally. The Silvering Screen: Old Age and Disability in Cinema. U of Toronto P, 2011.

Cloutier, Jean-Christophe. "A Country for Old Men: Unforgiven, The Shootist, and the Post-Heyday Western." Cinema Journal, vol. 51, no. 4, 2012, pp. 110-29.

Deleuze, Gilles. Cinema 1: The Movement-Image. Translated by Hugh Tomlinson and Barbara Habberjam, U of Minnesota P, 1997.

Deleuze, Gilles. Cinema 2: The Time-Image. Translated by Hugh Tomlinson and Robert Galeta, U of Minnesota P, 1997.

Dujakovic, Stela. "Masculinity Beyond Repair: Aging, Pathology, and the Male Body in Jonathan Franzen's The Corrections." Anafora, vol. 6, no. 2, 2019, pp. 469-91. Hrcak, DOI: doi.org/10.29162/ANAFORA.v6i2.9.

Flores, Suzana E. Untamed: The Psychology of Marvel's Wolverine. McFarland, 2018.

Foucault, Michel. The History of Sexuality. Volume 1: An Introduction. Translated by Robert Hurley, Vintage, 1990. 
Garland Thomson, Rosemarie. Extraordinary Bodies: Figuring Physical Disability in American Culture and Literature. Columbia UP, 1997.

Hawkins, Ty. Cormac McCarthy’s Philosophy. Palgrave Macmillan, 2017.

Holt, Douglas B., and Craig J. Thompson. "Man-of-Action Heroes: The Pursuit of Heroic Masculinity in Everyday Consumption." Journal of Consumer Research, vol. 31, no. 2, 2004, pp. 425-40.

Huw Bowen, Daniel. “The Uncertain Hope of Logan.” Fantastika Journal, vol. 1, no. 1, 2017, pp. 206-10.

JohnArthur. "No Country for Old Genres: McCarthy, the Coens, and the Neo-Western." The Artifice , 26 Nov. 2015, the-artifice.com/no-country-for-old-genres-mccarthy-the-coens-and-the-neowestern/. Accessed 28 Jan. 2020.

Kunow, Rüdiger. "Chronologically Gifted? 'Old Age’ in American Culture.”

Amerikastudien/American Studies, vol. 56, no. 1, 2011, pp. 23-44.

Lawrence, John Shelton, and Robert Jewett. The Myth of the American Superhero. William B. Eerdmans, 2002.

Ligor, Jakub. 'The Character of Anton Chigurh in the Coen Brothers' No Country for Old Men as an Expression of Reflections on Evil and Violence in American Culture." SEJ: Społeczeństwo.

Edukacja. Język, vol. 5, 2017, pp. 73-86.

Logan. Directed by James Mangold, Twentieth Century Fox, 2017.

Mangold, James. “Logan Director James Mangold's Essay on Shane.” Empire, 7 Mar. 2017, www.empireonline.com/movies/features/logan-director-james-mangold-essay-shane/. Accessed 16 Dec. 2019.

Mooney, Darren. "No Country for Old Man Logan: The Apocalyptic New West." The Movie Blog, 8 Mar. 2017, them0vieblog.com/2017/03/08/no-country-for-old-man-logan-the-apocalyptic-newwest/. Accessed 28 Jan. 2020.

Natale, Michael. "15 Films that Influenced Logan." CBR.com, 8 Mar. 2017, www.cbr.com/films-thatinfluenced-logan-movie/. Accessed 16 Dec. 2019. 
No Country for Old Men. Directed by the Coen brothers, Miramax Films, Paramount Vantage, 2007.

Paul, Heike. The Myths That Made America: An Introduction to American Studies. TranscriptVerlag, 2014.

Petković, Danijela Lj. "(Im)Possible Martyrdom: Masculinity, Aging, Illness, and Death in Tombstone and Logan." Collection of Papers of the Faculty of Philosophy, vol. 48, no. 3, 2018, pp. $121-50$

Puschak, Evan. “Logan: Superhero Movies Get Old.” Youtube, uploaded by Nerdwriter1, 25 May 2017, www.youtube.com/watch?v=pT75YHqID9k. Accessed 15 Dec. 2019.

Samajdar, Arup Ratan. "Tales of Violence and Revival: Persistence of the Mythic Hero in American Cinema." Colloquium: A Journal of the Arts Department, vol. 5, 2018, pp. 4-9.

Saxton, Benjamin, and Thomas R. Cole. "No Country for Old Men: A Search for Masculinity in Later Life." International Journal of Ageing and Later Life, vol. 7, no. 2, 2012, pp. 97-116.

Saxton, Benjamin, and Thomas R. "No Country for Old Men: Four Challenges for Men Facing the Fourth Age." Perspectives in Biology and Medicine, vol. 60, no. 4, 2017, pp. 607-14.

Steinberg, Graham. "How Logan Marries the Western Genre of the 1960s with the Superhero Genre of Today." Medium: B-Roll, 10 Jan. 2019, medium.com/b-roll/how-logan-marries-thewestern-genre-of-the-1960s-with-the-superhero-genre-of-today-8721c3b108d0. Accessed 28 Jan. 2020.

Travers, Peter. “Logan Review: Hugh Jackman's 'X-Men' Swan Song Is Bloody, Violent, Brilliant.” Rolling Stone, 28 Feb. 2017, www.rollingstone.com/movies/movie-reviews/logan-review-hughjackmans-x-men-swan-song-is-bloody-violent-brilliant-118496/. Accessed 6 Feb. 2020.

Tyrer, Pat, and Pat Nickell. "'Of what is past, or passing, or to come': Characters as Relics in No Country for Old Men." No Country for Old Men: From Novel to Film, edited by Lynnea Chapman King et al., The Scarecrow Press, 2009, pp. 86-94.

Welsh, Jim. "Borderline Evil: The Dark Side of Byzantium in No Country for Old Men, Novel and 
Film." No Country for Old Men: From Novel to Film, edited by Lynnea Chapman King, Rick Wallach, Jim Welsh, The Scarecrow Press, 2009, pp. 73-85.

Wheeler Vega, Jason A. "Generativity and Its Vicissitudes in Logan and the X-Men Series." Psychoanalytic Review, vol. 106, no. 5, 2019, pp. 455-74.

Yeats, William Butler. "Sailing to Byzantium." Poetry Foundation, www.poetryfoundation.org/poems/43291/sailing-to-byzantium. Accessed 7 Feb. 2020. 
[1] Aesthetically and geographically, Logan can certainly be seen as a neo-Western, despite the fact that it is a part of the superhero universe featuring characters with supernatural abilities.

[2] In his other works, Deleuze proposes differential ontology as a critique of identity (meaning: common, identical to all). Consequently, in Cinema 2, he returns to this by suggesting that the neoWestern depicts the shattering of the idea of American identity as a universal concept (216). Instead of looking at the global or universal, the focus is on the individual and particular - in this case, on the struggle of a man to come to terms with his own inadequacy and mortality.

[3] Although in Cinema 1, Deleuze writes about the neo-Western in 1983, referring to cinematic examples such as Anthony Mann's Man of the West (1958) or Sam Peckinpah's Major Dundee (1965) and The Wild Bunch (1969) (167), the popular culture perceives the Coens' No Country for Old Men (2007) as a film that (re)created a space for this new subgenre in the cinematic West (JohnArthur). Other notable examples include the Coens' True Grit (2010), Denis Villeneuve's Sicario (2015), David Mackenzie's Hell or High Water (2016), and Taylor Sheridan's Wind River (2017).

[4] The Coens' No Country for Old Men and Mangold's Logan, yield themselves to be viewed through the lens of generic transformation, a set of four creative modes outlined by John G. Cawelti in his seminal essay titled "Chinatown and Generic Transformation in Recent American Films" (1978), but the paper does not take this approach. Namely, Cawelti emphasizes the artistic vitality of the burlesque, which subjects traditional conventions "to some form of ironic or humorous exploitation" (250). Conversely, the titular films are notable for their bleak, nihilistic aesthetic and raw portrayal of violence, and deviate from parodying their narratives or the characters' treatment, rendering the burlesque approach to their neo-Western nature inapplicable. However, it should be noted that it was Tim Miller's Deadpool (2016), a "through-and-through burlesque superhero film that paved a way for Mangold's picture" (Puschak, "Logan: Superhero Movies Get Old"), namely in terms of its hard R-rating and raw, gritty tone.

[5] The ambiguity of Logan's identity and his role(s) is further emphasized by his multiple monikers, the analysis of which falls out of the scope of this paper. 
[6] This is perhaps largely due to the fact that genre treatment and character treatment are not mutually exclusive. Therefore, if one considers that, in No Country for Old Men, the Coens "invoke the Western genre only to dismiss it throughout" (Campbell et al. 319), whereas Mangold's Logan "shuns tropes associated with typical superhero films in favour of creating a cinematic pastiche" (Huw Bowen 207), the departure from traditional character development seems plausible enough to be analysed, as is the case in this paper.

[7] His remark is deeply ironical as he also suffers from the consequences of old age and is forced to take tranquilizing pills to briefly postpone the occurrence of lethal seizures caused by "a degenerative brain disease in the world's most dangerous brain" (Logan, 01:10:57 - 01:11:00).

[8] In one of the first among many reviews to draw parallels between Logan and the classic Western genre, Peter Travers notes that "Shane is directly referenced in one scene and the elegiac tone of the film recalls Clint Eastwood's Oscar-winning Unforgiven." However, rather than simply viewing Logan as a pastiche of these films' tonality and values, Samajdar considers it a loose reworking of both, but with a newly built template dependent on "refiguring and reaffirming the idea of the mythic hero" (7).

[9] In order to understand how Logan utilizes the conventions of all of the genres it hybridizes into the neo-Western, one has to be acquainted with its many influences. Alongside Shane and Unforgiven, James Mangold has confirmed in his essay published in the Empire that Akira Kurosawa's Yojimbo (1961), John Ford's The Searchers (1956), and Darren Aronofsky's The Wrestler (2008) have influenced the treatment of Logan's character as an aging, disabled frontiersman. The film's bleak, dystopian future takes cues from Alfonso Cuaron's Children of Men (2006), whereas his buoyant relationship with his "daughter" Laura and senile "father" Charles “owes a great debt to Luc Besson's Leon: The Professional (1994), Jonathan Dayton and Valerie Faris' Little Miss Sunshine (2006), Peter Bogdanovich's Paper Moon (1973), and Alexander Payne's Nebraska (2013)" (Natale).

[10] Nonetheless, Logan is oftentimes both violent and meditative, especially as an intimate portrayal and a revelatory study of three larger-than-life characters trying to cope with their age. From an old man tortured by world-paralyzing seizures and needing help to go to the bathroom, 
over a girl who can mercilessly hack and slash through walls of bodies in one scene, and ride a toy horse in front of a retail store in another, to a troubled, middle-aged alcoholic struggling to make ends meet and protect his family, Logan keeps pushing the viewer to contemplate aging and the issues surrounding it. In this regard, it surpasses the limitations of the bloated superhero flicks, grounding them in a brutal, yet easily palpable reality.

[11] Herein, he resembles two seminal Eastwoodian figures, namely Unforgiven's William Munny, "pictured failing at domesticity on the pig farm he has to leave in order to keep", and Little Bill, "the sheriff" and "an incompetent carpenter who finally builds his dream house" (Chivers 120).

[12] Canewood Beverage is one of the many corrupt corporations and Alkali-Transigen's cooperants whose highly addictive corn syrup sterilized the human body of any mutant genes. To produce and modify these gigantic amounts of corn, Canewood employed a number of violent methods, such as forceful purchase of the land on which they installed automated corn-harvesters, sabotage, scare tactics, as well as unlawful incursion.

[13] Logan's character arc echoes that of the eponymous protagonist of the classic 1953 Western titled Shane, a film which further popularized the hero archetype interwoven in many of the genre's later achievements. In this regard, Mooney rightfully observes that "Logan insists that the world (or the United States, at least) is too bleak and too cynical to allow for a real old-fashioned hero" ("No Country for Old Man Logan: The Apocalyptic New West"). Yet, somehow, the sacrifice of this oldfashioned hero serves a purpose greater than his own. It generates a possibility for Laura, his daughter, not to spend her life as a prisoner of old times, but rather as a harbinger of a new one.

\section{(c) (i) (9)}

Creative Commons Attribution-NonCommercial-NoDerivatives 4.0 International License 